\title{
Patriarchal ethics and narrative representation: Ethics, values and morality of the biblical narrator in the Jacob's story
}

\author{
Michael, Matthew \\ Stellenbosch University \\ Nasarawa State University, Nigeria \\ rabbimikhail@yahoo.com
}

\begin{abstract}
The patriarch narratives have continually become stories of ethical embarrassment to the modern readers because of the participation and support of the patriarchs for unethical practices which directly undermine the conception of these patriarchs as paragon of virtues and faith by later religious traditions. Implicated in the representations of the patriarchs are God and the narrator who largely distanced themselves, and also directly refused to make explicit moral condemnation of this unethical behaviour. Significantly, Yahweh persistently promises unconditional blessings and protections to these patriarchs in spite of their lying, deception, and cheating within the stories. To further reinstate this ethical dilemma, there are no divine thunderbolts, no wrathful confrontations or the outburst of divine holy anger that apparently addresses and punishes the moral flaws of these patriarchs. On this same ethical template, the narrator appears also sympathetic to the divine neglects of these unethical behaviours because in spite of these behaviours of the patriarchs and even matriarchs of his stories they were still largely considered the heroes and heroines of his stories. Departing from this general understanding of patriarchal ethics, the present study points to the subtle representation of Jacob's deception of his father and the punishment of this misdeed through his direct connection and implication in three subsequent scenes of deception where he himself was the object of these deceptions. Through this placement of Jacob in these other scenes of deceptions, the narrator subtly presents a moral universe where ethical misdeed continually haunts the perpetrators, and wrong deeds are clearly punished. Consequently, in spite of the many moral problems in the patriarch narratives, the narrator skilfully upholds a high morality, and the paper appropriately underscores the ethical significance of this representation of Jacob's story for the contemporary Christian community.
\end{abstract}

Keywords:

Jacob, biblical narrator, ethics, values, morality 


\section{Introduction}

The stories in the patriarchal narratives of Genesis have continually poised a formidable ethical problem to the modern reader. ${ }^{1}$ The narrative is unabashedly driven with an ethical perspective and moral orientation which are completely an embarrassment to the cultural and ethical sensitivities of the modern world. ${ }^{2}$ Like Søren Kierkegaard's comment on the sacrifice of Isaac, there appears to be the 'teleological suspension of the ethical' norms in the overall representations of the patriarchs in Genesis. ${ }^{3}$ In fact, the ethical representation of the patriarchs appeared to be clouded in moral ambiguity because of the participation of patriarchs in morally dubious practices. ${ }^{4}$ It seems the ethics and the values of the patriarchs are morally crude, embarrassingly shameful and primitively underdeveloped

1 David L. Petersen has described the problematic character of family values and ethical norms in the patriarchal stories of Genesis. For this study see David L. Petersen, 'Genesis and Family Values,' JBL 124, no. 1 (2005): 5-23.

2 See Michael J. Williams, Deception in Genesis: An Investigation into the Morality of a Unique Biblical Phenomenon. Studies in Biblical Literature, vol. 32 (New York: Peter Lang, 2001); Dean A. Nicholas, The Trickster Revisited: Deception as a Motif in the Pentateuch (Oxford: Peter Lang, 2009); John E. Anderson, Jacob and the Divine Trickster: A Theology of Deception and Yhwh's Fidelity to the Ancestral Promise in the Jacob Cycle (Winona Lake: Eisenbrauns, 2011).

3 Concerning Abraham's suspension of his ethical duty to his son, Søren Kierkegaard said, 'Abraham's relation to Isaac, ethically speaking, is quite simply expressed by saying that a father shall love his son more dearly than himself. Yet within its own compass the ethical has various gradations...in this story there is to be found...higher expression for the ethical...' which 'ethically explain his conduct, ethically justify him in suspending the ethical obligation toward his son, without in this search going beyond the teleology of the ethical.' See Søren Kierkegaard, Fear and Trembling (Radford, VA: Wilder Publication, 2008), 39-48, see page 41; Howard Moltz, 'God and Abraham in the Binding of Isaac,' JSOT 96 (2001): 59-69. See also Ronald M. Green, 'Abraham, Isaac, and the Jewish Traditions: An Ethical Reappraisal,' The Journal of Religious Ethics 10, no. 1 (1982), 1-21; Edward F. Mooney, 'Abraham and Dilemma: Kierkegaard's Teleological Suspension Revisited,' International Journal for Philosophy of Religion 19 (1986): 23-41.

4 There are at least three ethical concerns which the act of narrating itself poses for the general crafting of stories. Zachary Newton has identified these three ethical concerns in terms of narrational ethics, representational ethics and hermeneutical ethics. By narrational ethics, Newton is primarily concerned with the consequences and ethical issues generated by the narrative act itself and, in talking of the representational ethics he meant the ethical issues at the heart of fictionalizing oneself and other from 'person' to 'character.' Lastly, Newton describes the hermeneutical ethics which basically deals with the ethical responsibility that the act of reading the story imposes on its readers. In patriarchal narratives, there are these three ethical concerns, however, the attention of the present work is primarily tailored to address the first and the last. See Adam Zachary Newton, Narrative Ethics (Cambridge, MA: Harvard University Press, 1995). 
since the moral universe inhabited by the patriarchs allowed and tolerated lying, cheating, stealing and duplicity among characters who later will be deemed the paragon of Jewish faith and Christian virtues. ${ }^{5}$

Due to their importance as venerated religious symbols, there is a quest to quickly repress these ethical problems in the representations of the patriarchs in a salvation-historical scheme or the rhetoric of fallenness in traditional Christian scholarship which immediately saw the moral flaws of the patriarchs in terms of the fall, and its attending degenerating influence on the morality of the human race. ${ }^{6}$ In this regard, the lives of the patriarchs best staged and showcased the moral predicament of the human race as encapsulated in the earlier story of the Adamic fall. ${ }^{7}$ Similarly, there is also the quest to whitewash and reverse this embarrassing ethical portrait by overcompensation, and the deliberate exaggeration of the virtues of the patriarchs in early rabbinic interpretations. This path is largely taken in order to neutralize the unpleasant ethical practices of the patriarchs. In early rabbinic interpretation also, there is the outright denial of the reported cases of unethical behaviour by characters within the patriarchal narratives. For example, commenting on Reuben sleeping with his father's

5 These unethical behaviours of the patriarchs go against the argument in modern critical scholarship that the lives of the patriarchs were written in Genesis to be a model for communities of Israel in Exile. For this treatment of Abraham as ideal model for the exilic community see Joseph Blenkinsopp, 'Abraham as Paradigm in Priestly History of Genesis,' JBL 128, no. 2 (2009): 225-241. Underscoring this same view and speaking of Yahwist in Genesis, Christoph Levin observed, 'The editor often brings the dialogue down to basic principles, which apply independently of the scene described and are designed to make the reader transfer the point to his own experience of life. They underline the efficacious presence of Yahweh. Many of them have an ethical trend. 'It is not good that the man should be alone' (Gen 2:18) is the first example of this kind, spoken before the creation of the woman. Many others follow: 'I will bless you so that you will be a blessing' (Gen 12:2); 'Is anything too hard for Yahweh?' (Gen 18:14).' [See Christoph Levin, 'The Yahwist: The Early Editor in the Pentateuch,' JBL 125, no. 2 (2007), 227]. Unfortunately, this way of looking at the patriarchs as models for their readers ignored or relativized the defining role of the unethical practices associated with the patriarchs of Genesis.

6 Despite its pioneering status in Old Testament ethics, Christopher J. H. Wright, Old Testament Ethics for the People of God, failed to clearly address the unethical behaviours of the patriarchs. See Christopher J.H. Wright, Old Testament Ethics for the People of God (Leicester, England: Inter-Varsity, 2004), 473-475.

7 See Michael F. Bird, on the 'patriarchs and Israel' in redemptive history in Evangelical Theology: A Biblical and Systematic Introduction (Grand Rapids, Michigan: Zondervan, 2013), 500-506. 
wife Bilhah in Genesis 35:22, Rabbi Shmuel Bar Nahman said, 'Anyone who claims that Reuben sinned is mistaken. ${ }^{8}$ Similarly, on the deception of Jacob in Genesis 27:34-35, the biblical narrative reads: 'When Esau heard his father's words, he burst out with a loud and bitter cry and said to his father, 'Bless me - me too, my father!' But he said, 'Your brother came with mirmah [hm'r $>$ mi] and took your blessing.' While 'mirmah' literally means 'deception' the rabbis saw this word 'in the sense of ingenuity and acumen gained in the study of Torah.' ${ }^{9}$ Thus commenting on this scene of deception, Rabbi Yohanan said, Jacob 'came with the wisdom of his Torah' and took away Esau's blessings. ${ }^{10}$ Describing this rabbinic practice, Pesach Schindler observed, there is '...the tendency in early rabbinic literature to excuse negative behaviour of biblical personalities. This left its mark on subsequent biblical commentaries of the Middle Ages.' According to Schindler, 'Such defending' of the virtues of the patriarchs 'would appear even when the close reading of the scriptural text points in opposite directions. ${ }^{11}$ Unfortunately, the patriarchs in Genesis are often portrayed in a dark moral climate and savage ethics, so that even the projected virtues of their lives in the pious eyes of these later religious traditions have not been able to revise the ethical problems presented by their involvement in and support for questionable moral behaviours. ${ }^{12}$

8 Pesach Schindler, 'Jacob and Esau Revisited: Demon versus Tzadik,' Jewish Bible Quarterly 35, no. 3 (2007), 153.

9 Schindler, 'Jacob and Esau Revisited,' 154.

10 Schindler, 'Jacob and Esau Revisited,' 154.

11 Schindler, 'Jacob and Esau Revisited,' 153.

12 To this tendency, Gerhard von Rad observed, 'When we pursue the question of the principal force forming the saga we stumble upon a state of affairs which, so far as we can see, basically separates the Old Testament saga from all sagas of the world. Everywhere else there is a tendency to transfigure and idealize the characters, to create ideal images in which the people becomes transfigured and by it is edified. In the Germanic sagas, for example, it is the popular ideals of loyalty, courage, and readiness for death, of noble kings with their retinue, which the recollections of a remote past now illumine. Here, therefore, real idealizing fiction is involved. Compared with this, the difference in the Old Testament sagas as ideal images, is completely missing. The figures of the patriarchs as well as the events of the period of Moses are painted with a sober realism which in no way suppresses great and uplifting human traits but nevertheless it is downright painstaking in presenting weakness, sin, and failure with unmitigated rigor. The reason is obvious. All sagas as we have them are concerned much less with men than with God...It is a real question whether Abraham, Jacob, or Joseph in any sense ever had the character of models for later generations, which should spur them 
Departing from these approaches, the present study engages the representation of Jacob within this ethical sensitivity, but it notes literary clues in this representation that points to narrator's ethical stand on the participation of the patriarchs in these unethical behaviours. ${ }^{13}$ Taking the deception of Jacob of his father as a case in point, the study reveals the subtle condemnation of this unethical behaviour by the involvement and connection of Jacob with other scenes of deceptions within the Jacob's cycle, thus reinstating the narrator's point of view that measure for measure, nemesis or retributive justice attends the patriarchal misbehaviour. ${ }^{14}$ By this association, the narrator subtly presents a narrative universe where unethical behaviours are not entirely condoned.

\section{The narrator and the ethical representations of the patriarchs}

The narrator has often important ideological ties to the characters he or she assembled on the narrative stage, particularly the representations of the heroes and the heroines of his or her stories. ${ }^{15}$ Through these characters,

on to imitation and discipleship.' See Gerhard von Rad, Genesis: A Commentary, trans. John H. Marks (Philadelphia: The Westminster Press, 1959), 34.

13 There is the quest in contemporary scholarship particularly within the Christian community to draw from Old Testament ethical template which will guide the present Christian life. In this sense, there is the quest to redeem morally problematic biblical texts for the contemporary Christian community. For this study see M. Daniel Carroll et al, eds. Character Ethics and the Old Testament: Moral Dimensions of Scripture (Louisville, KY: Westminster, 2007). See also Gordon J. Wenham, Story as Torah: Reading the Old Testament Ethically (Edinburgh: T. \& T. Clark, 2000); Robin Parry, Old Testament Story and Christian Ethics: The Rape of Dinah as a Case Study (Milton Keynes: Paternoster Press, 2004); John Barton, Understanding Old Testament Ethics: Approaches and Explorations (Louisville, KY: Westminster John Knox Press, 2003).

14 The selection of the Jacob's story as the central narrative in understanding the patriarchal ethics comes from the recognition of the paradigmatic character of the Jacob's story. For this study see Joseph Blenkinsopp, Treasures Old and New: Essays in the Theology of the Pentateuch (Grand Rapids, Michigan: Eerdmans, 2004), 137-154. Blenkinsopp titled this chapter, 'Biographical Patterns in Biblical Narrative: Folklore and Paradigm in the Jacob Story.'

15 Describing the neglect of the ethical dimension in the studies of the representation of characters in biblical scholarship, Wenham observed, 'Serious biblical scholarship has traditionally been concerned almost entirely with historical questions, how and when the text originated, what it tells us about Israel's political and religious history, and so on. The purpose of the writer in telling particular stories and the message that a particular book was intended to convey has been given a low profile in biblical study, 
one could discern or engage the values and ethics of the narrator by the way they are represented in a particular work. ${ }^{16}$ In this sense, the heroes and heroines often masked the ideals, values and ethical ideologies of the narrator who placed these characters in narrative stage, and through these leading characters further promote indirectly a particular ethical norm or morality. Meir Sternberg rightly observed, '[f]ar from sui generis,' biblical narrative 'then falls squarely under the universal rule of representation, whereby the represented and the real world always interrelate. ${ }^{\prime 17}$ Since the values of the heroines and heroes of a particular narrative have important bearings on the narrator's values, the ethical representation and the attitudes of the narrator towards the heroines and heroes of a story have direct importance in the recovery of the moral universe and discourse behind a story. Significantly, there is a profound relationship between the ethical system in a story and its character construction. According to Marta Figlerowicz, 'character construction is often where fiction reveals its ethical and social stakes most candidly. ${ }^{38}$ In this regard, characters in a narrative generally either mimics, challenges or endorses a particular ethical stand. At any rate, characters are the ethical mouthpiece of the narrator who employed them to endorse or challenge a particular ethical view. Character construction is primarily an ethical enterprise because the representations of characters in a story subtly seeks to influence the reader towards the ethical system or norm championed by the narrator/author. Considering this ethical mapping of stories, Gordon Wenham observed, ethnical 'norms are embodied in texts...' and 'literary works do have ethical

and where it has been discussed the focus has been on a work's theology rather than its ethical stance.' Concerning the ethical intention of the narrator in Genesis, Wenham said, 'Thus interpretations of Genesis tend to see it as a book about creation, fall and the call of the patriarchs. Yet in the Bible Genesis is seen as the first book of the law (Torah), although it is nearly all narrative. Jesus and Paul, Jewish rabbis and Christian preachers, all appeal to Genesis to demonstrate truths about human behaviour and draw out principles of ethics. ...Genesis certainly looks as though it may be trying to teach ethics as well as theology, but there are quite contradictory conclusions drawn by eminent scholars as to what that ethic is.' See Wenham, Story as Torah, 2.

16 On the border issues between narrativity and fictionality see Richard Walsh, 'Fictionality and Mimesis: Between Narrativity and Fictional Worlds,' Narrative 11, no. 1 (2003): 110-121.

17 See Meir Sternberg, The Poetics of Biblical Narrative: Ideological Literature and the Drama of Reading (Bloomington: Indiana University Press, 1987), 36.

18 Marta Figlerowicz, 'Bounding the Self: Ethics, Anxiety, and Territories of Personhood in Samuel Beckett's Fiction,' Journal of Modern Literature 34, no. 2 (2011), 77. 
values of which they are explicitly or implicitly trying to convince their readers. ${ }^{19}$ Shimon Bar-Efrat also said, '[b]ecause the author also conveys values to us through the characters, it is important that we understand their actions and assess them correctly. ${ }^{20} \mathrm{He}$ added,

[while b]iblical narrators' objectivity and lack of tendentiousness in representing characters and events has often been noted...[i]n actual fact, there is no such thing as a totally objective narration, for even if they do not conceal the characters' negative aspects and use a controlled and factual style, as biblical narrators do, this does not mean that they remain impartial towards their protagonists [heroes/ heroines]. It is true that their stance is indicated by implication rather than explicitly or obtrusively, but this method is no less efficacious than the direct and obvious one. On the contrary, just because it is not conspicuous and functions covertly, it tends to be more effective in transmitting narrators' values to the readers. ${ }^{21}$

In this sense, the heroes and heroines of a particular story are often the moral embodiment of the narrator and tell us about the narrator's values through his attitudes towards the moral and ethical choices of his leading characters. Narrative in this important aspect makes the morality of the leading characters also the morality of the narrator particularly when the narrator appears to side with the heroes and heroines of the story. Consequently, the moral and immoral representations of the leading characters in events and plots of the story could readily inform the readers of the ethical imagination which largely shaped and impacted the telling of the story.

19 In addition, Wenham also said, 'Writers, whether of fact or fiction, write with a view to influencing their readers to think or act in a certain way. Authors convey their own outlook through their poetry or prose and seek to share it with their readers; they hope that as a result of their writing their readers will come to accept their own point of view to a greater or lesser extent. Indeed arguably one of the marks of great writers is that they write with persuasiveness convincing the reader of the rightness of their viewpoint. Since a study of narrative ethics is essentially an attempt to elucidate the writer's outlook, it usually matters very little whether the story that is told is fiction or history.' See Wenham, Story as Torah, 11, 6.

20 Shimon Bar-Efrat, Narrative Art in the Bible (New York: T\&T Clark, 2004, reprint 2008), 30.

21 Bar-Efrat, Narrative Art in the Bible, 32. 
Seen from this angle, the moral representations of these leading characters are iconic pointers to the morality and values of the narrator. People in fiction as well as in real life often shared the moral assumptions of their heroes and heroines and they often identify with the ethical or moral universe of these individuals. In real life, for example, the pictures of Mahatma Gandhi, Che Guevara, Nelson Mandela or Martin Luther King in a particular house or place tell the visitor to this house or place in many ways the ideals and values of the owner of the defined space. In the same way, the pictures of pop icons such as Michael Jackson, Shakur Tupac, Lady Gaga or Rihanna in a given room also speak to the visitor the values and ideals of the owner of the room or the said space. In the same way, the ideals and values of the narrator is hidden in his/her ethical representation of the leading characters and the moral attitudes towards them. The task of discovering the ideals and values of narrative demands the engagement with this subtle aspect of stories. Concerning this task, Wayne Booth advised,

The problem for the reader is thus really that of discovering which values are in abeyance and which are genuinely, though in modern works often surreptitiously, at work. To pass judgment where the author intends neutrality is to misread. But to be neutral or objective where the author requires commitment is equally to misread... ${ }^{22}$

Considering the preceding, the ethical representations of leading biblical characters become important particularly where leading biblical characters are consistently staged in morally ambiguous or morally problematic stories. In the patriarchal universe, it seems morality is largely fluid without the ethical boundaries and restrictions of the later biblical traditions. In this moral universe, for example, Sarah unabashedly lied to God, Abraham lied two times in a difficult situation, Tamar deceived her father-in-law, Jacob's children deceived the Shechemites and Jacob himself, and Jacob also deceived his blind father through the orchestration of his mother Rebekah. In the patriarchal narratives, we also see Sarah's mistreatment of Hagar, Abraham's banishing of his surrogate wife Hagar, Laban's deceptive and unethical exploitation of Jacob, and Judah sleeping with his daughter-in-law Tamar. In addition, Abraham nearly killed his son Isaac,

22 Wayne Booth, Rhetoric of Fiction (Chicago: University of Chicago, 1961), 144. 
thus jettisoning his fatherly responsibility to Isaac in order to obey God, and the brothers of Joseph nearly killed him, though they later sold him into slavery, thereby jettisoning their fraternal bond of brotherhood to him. ${ }^{23}$ Similarly in terms of its ethical problem, 'Sarah's strategy' in giving Hagar to Abraham for sex and procreation has been termed 'polycoity.' Among anthropologists, 'polycoity' describes a family whereby 'one male has sexual access to more than one female.' ${ }^{24}$ While this marital practice is clearly attested in several ancient cultures, its adoption by Abraham's household appears to suggest the ethical imprisonment of the patriarchs to the socio-cultural norms of their time. ${ }^{25}$

Interestingly, despite the problematic character of these preceding events in the patriarchal narratives, and its obvious conflicts with mosaic legislation, we do not see a divine thunderbolt or anger directed against these ethical misdemeanours. Rather, Yahweh is often represented as blessing these characters and appearing to tacitly support their moral duplicities by his unconditional promise of blessings vouchsafed to them. ${ }^{26}$ For example, in spite of Sarah's brazen lie, Yahweh still proclaimed his desire to give Abraham a son through Sarah (Gen 18:10-15). Concerning this scene, Moshe Reiss observed, '...Then in their only direct interchange, God accuses Sarah of lying...' and still went ahead to promise his blessing to Abraham. ${ }^{27}$

Similarly, the narrator, for example, presents Abimelech, a pagan king in a better light than Abraham. ${ }^{28}$ Remarkably, while Abraham lied to Abimelech about Sarah, Yahweh himself commended the integrity of

23 Petersen, 'Genesis and Family Values,' 15.

24 Petersen, 'Genesis and Family Values,' 17.

25 Concerned about these unethical practices, S. R. Driver observed that the patriarchal narrative was generally 'addressed to men who, through far from uncivilized...were nevertheless in many respects spiritually immature.' See S. R. Driver, The Book of Genesis (London: Methuen, 1904), lxxiii.

26 According to Anderson, Yahweh himself is morally implicated in this representation of Jacob as a deceiver because he supports and promises the ancestral blessings to this dubious character. See Anderson, Jacob and the Divine Trickster, 1-210.

27 Moshe Reiss, 'The God of Abraham, Rebekah, and Jacob,' Jewish Bible Quarterly 32, no. 2 (2004), 92.

28 Von Rad has also acknowledged the 'moral problem' with the earlier story of Abraham's lying about Sarah in Genesis 12:10-13:1. He describes 'lie and betrayal' of Sarah. By such act, von Rad observed that 'the bearer of promise himself' namely Abraham was 
Abimelech (Gen 20:4-6). Concerning this same incident, Bruce K Watke said, 'Abimelech feared God more than Abraham did!'29 This recognition showcases the moral problems and ethical ambiguity in the representation of the patriarch, and the gross inadequacy of the patriarchs' morality. To this end, Adriane Leveen observed that the patriarchal narratives, '... suggest that non-Israelites may in fact be proven even more trustworthy than the patriarch... ${ }^{30}$ Similarly, John Skinner said, '[i]t is assumed that in the circumstances lying is excusable. There is no suggestion that either the untruthfulness or the selfish cowardice of...[Abraham] was severely reprobated by the ethical code to which the narrative appealed. ${ }^{31}$ Herman Gunkel notes that the narrator of the patriarch narratives 'silently rejoices that Abraham had lied so extraordinary well and made a virtue out of a necessity. ${ }^{32}$

In these different stories, the moral bearing of the Patriarch narratives appeared less ethically satisfying because it describes a moral universe peopled by crooks who, morally speaking, lack ethical consideration and thereby render inappropriate the divine pampering or promise of blessings to them..$^{33}$ While it is grossly unfair to judge the patriarchs by the ethics and moral standards of the modern period, the moral inclination of the patriarchal narratives raises an ethical problem because the God of the patriarchs appears to be morally neutral to their unethical behaviour. Within this ethical mapping, the narrator rarely indicates or comments on the moral flaws of these patriarchs or connects these moral misdemeanours to any form of punishment. Concerning deception, and the failure to punish

the 'greatest enemy of the promise' because 'it greatest threat comes from him.' See von Rad, Genesis, 162-165, especially pages 163-164.

29 Bruce Watke and Cathi J. Fredericks, Genesis (Grand Rapids, Michigan: Zondervan, 2001), 287.

30 Adriane Leveen, 'Reading the Seams,' JSOT 29, no. 3 (2005), 280.

31 John Skinner, A Critical and Exegetical Commentary on Genesis. ICC (Edinburgh: T\&T Clark, 1930), 249.

32 Herman Gunkel, Genesis (Göttingen: Vandenhoeck \& Ruprecht, 1977), 170.

33 Female characters were also involved in these acts of deception and trickery in Genesis. For this study see Melissa Jackson, 'Lot's Daughters and Tamar as Tricksters and the Patriarchal Narratives as Feminist Theology,' JSOT 98 (2002): 29-46; on the general role of female gender in the representation of the trickster traditions see also Margaret A. Mills, 'The Gender of the Trick: Female Tricksters and the Male Narrators,' Asian Folklore Studies 60, no. 2 (2001): 237-258. 
this act in patriarchal narratives, $\mathrm{O}$. H. Prouser said, ' $[\mathrm{t}$ ]hroughout biblical narrative, deception is considered a legitimate tool for less powerful people to use in order to succeed. In addition to not being punished for their actions, tricksters are often rewarded and applauded for their cleverness. ${ }^{34}$ Similarly, Stuart Lasine has described the Patriarchal narratives as a 'safer world' which is freed from the 'lethal danger' associated with the divine being in the Hebrew Bible. ${ }^{35}$ Thus it seems the narrator of the patriarchal narratives allowed the patriarchs and matriarchs of Genesis to roam the narrative universe without the mooring of divine punishment.

Significantly, Sternberg has readily shown that the biblical narrator is not a didacticist, that is, the narrator is not out to convey some moral lessons, but through his characterization it is possible to discern his moral point of view or values that inform and guide his representation of events and characters in his stories. ${ }^{36}$ Similarly, Bar-Efrat has underscored the significance of the narrator's point of view in his representation of the characters and the general narrative landscape of his story. He observed, '...the point of view

34 O. H. Prouser, 'The Truth about Women and Lying,' JSOT 61 (1994), 16.

35 See Stuart Lasine, 'Everything Belong to Me: Holiness, Danger, and Divine Kingship in the Post-Genesis World,' JSOT 35, no. 1 (2010): 31-62.

36 Denying the place of didacticism in biblical narrative, Sternberg said, 'Now, if biblical narrative is didactic, then it has chosen the strangest way to go about its business. For the narrator breaks every law in the didacticist's Decalogue. Anything like preaching from the narrative pulpit is conspicuous for its absence. So is its immemorial mate and nearest equivalent-black-and-white delineation of agents, motives, causes, processes. Instead of polarizing scheme of values, the Bible habitually generates ambivalence: consider Jacob... Rather than aligning divine election and moral stature, it usually foregrounds their discordance. Rather than imposing an automatic or at least intelligible system of rewards and punishments, it undermines every rule of thumb, every simple proportion. Its commissions even radicalize the unsettling effect of its doctrinal omissions, by diverting notice, as it were, from all-important focus of interest. The characterization is complex, the motives mixed, the plot riddled with gaps and enigmas, behaviour unpredictable, surprises omnipresent, the language packed and playful, the registration of reality far more governed by the real and the realistic than by the ideal. In short, where didacticism would insist on subordination, one encounters proliferation; where the discourse should move in a straight line, it weaves a net; where propositions should readily follow from premises, the premises themselves often remain ambiguous or double-edged and the propositions become multiple; where transparency is expected, we have to struggle with opacity on all levels, from word to world to thought... To my mind, all this shows beyond doubt that the whole idea of didacticism is alien, if not antipathetic, to the spirit of Israelite storytelling and has been imported from later philosophical and religious traditions...' See Sternberg, The Poetics of Biblical Narrative, 37-38. 
is one of the means by which the narrative influences the reader, leading to the absorption of its implicit values and attitudes. ${ }^{37}$ More forcefully than Sternberg and Bar-Efrat, Wenham has described the need to 'identify' the 'ethical norms and values' in biblical stories in order to discover the 'didactic purpose' of these stories. ${ }^{38}$

Situating the present study in this ethical landscape, the work describes a subtle relationship between ethical misdeed and punishment in the story of Jacob, and thereby suggests that the narrator of Genesis did not situate his characters in an ambiguous moral universe but points to the culpability of the misdeeds of the patriarchs in the close reading of these stories. In this regard, the work describes a subtle connection between the misdeeds of Jacob in his youth and the seeming punishment of these misdeeds throughout his adult life. Using the ethical system of 'a measure for a measure,' or a kind of nemesis, the narrator retributively shows the subtle ways in which Jacob's earlier deception of his father is restaged in the repeated scenes of deception where Jacob himself becomes the object of these deceptions. The narrator accomplishes this feat not through direct moralizing comments or the obvious statement of his moral verdict against Jacob, but through an indirect means which pits the earlier deceptions of Jacob against the other scenes where Jacob himself becomes also a victim of deception.

\section{Deception and retribution in Jacob cycle}

The story of Jacob is an appropriate place to begin our quest to show the connection between an unethical act and the corresponding retribution in Patriarchal ethics. First, the story of Jacob and its extended version in the Joseph's narrative has more space in the book of Genesis. The narrator appears to give the character of Jacob a lengthy space with an important narrative attention. Blenkinsopp describes Jacob as the 'cumulative character' in Genesis because ' $\mathrm{t}$ ] aken in its entirety, the life story of Jacob from conception to death covers about half of the book of Genesis (25:1950:14).' Therefore, according to Blenkinsopp, '[t]he paradigmatic intent

37 Bar-Efrat, Narrative Art in the Bible, 16.

38 See Wenham, Story as Torah, 6, 11. 
is evident throughout the Jacob story.' ${ }^{39}$ Similarly, the narrator appears to also underscore the ideological importance of Jacob in the narratives of Genesis by the way he stretched the character of Jacob, and the stress on this character for the subsequent emergence of the nation of Israel. In this way, the character of Jacob serves as an ideological bridge which links the story of the patriarchs together, particularly the story of Abraham to the story of Joseph. Lastly, Jacob himself appears to canonize or embody the ethical and moral ambiguity of the patriarchal narratives we have discussed so far. In fact, this moral ambiguity is both seen in his name and misdeeds. Unlike other patriarchs with good names, Jacob stands alone as the character named the 'supplanter' or 'deceiver,' or in the description by Blenkinsopp, a 'fraudulent' and 'crooked' character. ${ }^{40}$ According to Melissa Jackson, '[t]he Hebrew Bible has itself also bequeathed us many tricksters. Jacob is probably its best known. ${ }^{31}$

Seen from this perspective, his name as well as his deed embodies this moral ambiguity and problematic unethical practices which characterized the patriarchs and matriarchs of Genesis. As the embodiment of the moral ambiguity of the patriarchal narratives, a study in the characterization of Jacob in terms of its ethical orientation will help to provide clarity to the ethical commitment of the narrator. In these different levels of significance, the choice of the character Jacob for the present discourse is not accidental because as a dubious character, Jacob certainly represents and embodies the moral ambiguity of the patriarchal narratives. Consequently, the representation of Jacob as the subject of unethical behaviour and its corresponding retribution in this paper clearly has justification. In this particular sense, Jacob reflects these convergences of sin and its retribution or the subtle presence of nemesis in this story.

Considered in this way, the Jacob's cycle presents this subtle narration and characterization of Jacob. For example, the Jacob's cycle underscores the moral flaws of Jacob. First, the narrator of the Jacob's cycle describes the unethical treatment and behaviour of Jacob towards his twin-brother Esau. Jacob exploited the hunger of his brother in order to secure for himself

39 Blenkinsopp, Treasures Old and New, 137-154.

40 Blenkinsopp, Treasures Old and New, 147.

41 Melissa Jackson, 'Lot's Daughters and Tamar,' 31. 
the birth right. Traditional scholarship has often demonized Esau without actually noting clues in the stories which go against these New Testament sentiments. Placed in its proper context, Abraham in Genesis 18 typifies generosity and hospitability towards strangers. In this passage, Abraham is represented as an embodiment of hospitality by his provision of food to three total strangers. Consequently, one would have expected that Jacob will model this same representation exemplified by Abraham through the provision of food to his hungry brother. In the case of Jacob, he immorally exploited the hunger of his brother and exploited the predicament of his brother to further his own personal agenda. In Old Testament ethics, hospitality and goodwill to the hungry and the poor was particularly commanded. However, Jacob reneged on this Old Testament ethics and exploited the hunger of his brother in order to pursue his own selfish ends. In this way, the narrator represents Jacob in bad light, because he is represented as a terrible schemer and a base fellow who exploited the hunger of his twin-brother in order to get the birth right of Esau. Seen from this perspective, Jacob possibly embodies here the immoral and unethical character of the entire patriarchal narrative, because his character is generally conceived as eponym of the nation of Israel. Importantly, the narrator represents an immoral character who exploited the hungry for his selfish desire to acquire the birth right. Yet, in spite of this representation, there is no immediate reprimanding from God which challenges or frowns at this misdeed of Jacob. The narrator did not marshal heavenly thunderbolts and divine anger in response to this unethical practice of Jacob. The values and ethics of Jacob at this point present a moral problem. One would have expected Yahweh to kill or maim Jacob just like he killed Er and Onan who wanted to sexually exploit the wife of their late brother (38:1-30). In this same plain of sibling exploitation, the story of Jacob coheres with the one of Er and Onan, but they were immediately punished for their sexual exploitation, while Jacob was divinely spared from the experience of divine judgment in spite of his raw scheming and exploitation of his brother, Esau. ${ }^{42}$

On the second incident in the moral representation of Jacob's story. We saw Jacob seeking also to deceive his blind father. The unethical character

42 Diane M. Sharon, 'Some Results of a Structural Semiotic Analysis of the Story of Judah and Tamar,' JSOT 29, no. 3 (2005), 300-318. 
and exploitative nature of this scene of deception is no doubt obvious. ${ }^{43}$ In this story, Jacob was motivated and influenced by his mother Rebekah, who disguised him as Esau in Esau's clothing in order to deceive his blind father. Clothed with Esau's dress, and covered with the goat's skin on his arms and neck, Jacob dubiously deceived his blind father by impersonating Esau. 'Exploitation of a father's weakness is...' according to Wenham, 'seen in Jacob deceiving his blind father Isaac. ${ }^{44}$ While there is no need to rehearse this story here since it is well-known, however, the unethical and immoral character of this scene has often been quickly spiritualized or justified by a reference to the earlier prophecy whereby Rebekah was assured of Jacob's supremacy over Esau, and the sovereign conferment of covenantal blessings on him which by rights of primogeniture belongs to Esau (Gen. 25:20-26). The moral compass in the treatment of this story within the thematic prism of divine sovereignty often fails to engage the unethical representation of Jacob who once again exploited the blindness of his old aged father in order to get his blessing. In tears, Esau wept in Genesis 27:36 that he has been deceived or 'Jacobed' twice. ${ }^{45}$ Complementing the preceding characterization, it appears Jacob preyed on the weakling, whether they are the hungry or the blind, and thereby contributing to the moral ambiguity of his character and the problematic nature of Yahweh's sovereign election in the first place. From this moral prism, it is pertinent to note that, even though it is anachronistic to refer to the Mosaic Law at this point, Jacob appears to break that legislation in several fronts. For example, by deceiving his father, he went against the Mosaic legislation which commanded that children should honour their father and mother. In a mocking way, Jacob appears to honour his mother and dishonour his father. Similarly, he also coveted and took over his neighbour's property which clearly goes against the Mosaic instruction in the Ten Commandments. ${ }^{46}$ In addition, he stole his brother's blessings, which also went against the Mosaic commandment,

43 According to Blenkinsopp, '[i]n the present narrative...one suspects not only that the juxtaposition of these traditional motifs will be disturbing to most readers but also that the writer is conscious of moral ambiguity.' See Blenkinsopp, Treasures Old and New, 150 .

44 Wenham, Story as Torah, 28.

45 See Blenkinsopp, Treasures Old and New, 150.

46 The place of the tenth commandment in modern society has continually been debated. On this discourse see Joseph Hester, The Ten Commandments: A Handbook of Religious, Legal and Social Issues (Jefferson, NC: McFarland, 2003), 1-285. 
'do not steal.' ${ }^{\text {47 }}$ Jacob also gives a false representation of himself before his father, thereby exalting falsehood and lies which are directly forbidden in the ninth commandment. Even though the passage is often debated in traditional scholarship, it seems Jacob was also involved in the practice of sympathetic magic in Genesis 30:25-43, and have graven images or possibly knowledge of graven images in his household (35:1-5).

Interesting, there are subtle indications that the narrator counteracted these moral flaws and negative aspects in his characterization with appropriate retribution of his different acts of deception. First, for deceiving his blind father, the narrator presents three important places where Jacob was also deceived by other characters in the story. ${ }^{48}$ These scenes of deceptions include Laban's deception of Jacob in Genesis 29:15-30; Rachel's deception of Jacob in Genesis 31:22-42; and Jacob's deception by his children in Genesis 37 when they killed a goat and poured the blood on the garment of Joseph in order to deceive their father that a wild animal has killed Joseph (vv. 31-35). One can also add the earlier Shechemite incidence in Genesis 34:1-31 when the children of Jacob again deceived him alongside with the Shechemites. In these critical places in Jacob's story, the narrator without didactic intention laid bare the return of judicial nemesis to haunt Jacob for the deception of his blind father. Jacob is the only character in Genesis who in three or four places is implicated in, and the direct object of, deception. It seems the narrator points to the ethical mapping of his story namely 'measure for measure' and the principle that wrong deeds ultimately come back to haunt their perpetrators. ${ }^{49}$

47 According to Blenkinsopp, '[t]he story of the deception' of Isaac by Jacob 'is told straight through with no authorial intervention or tongue-clicking and no unnecessary side-tracking.' Consequently, the inferred view of the narrator is hidden here. See Blenkinsopp, Treasures Old and New, 150.

48 Blenkinsopp, describing this scene of deception said, the narrator 'records the emotions of the actors - the cool, calculated approach of Rebekah and the conniving attitude of Jacob contrasted with the violent trembling of the old man and the great and bitter cry and the tears of Esau on discovering the deceit (vv. 33-34).' See Blenkinsopp, Treasures Old and New, 150.

49 Song-mi Suzie Park, for example observed, '[The] notion of retributive justice is found also in the patriarchal narratives. Jacob who dupes his brother (Gen 27), is in turn duped by his uncle (Genesis 29); Rebekah, who helps Jacob steal the blessing from his brother Esau, is doomed never to see her favorite son again (Gen 27) and Joseph's brothers, who sell Joseph into slavery, in turn, are tormented and then saved by the very brother (Gen 37) whom they bullied and sold into slavery.' Song-mi Suzie Park, 'The 
Looking closely at these subsequent scenes of deception, one realizes that there are several connections of these scenes of deception to his original deception of his blind father Isaac. Like the deception of his father, he was also deceived by his uncle Laban when he gave him Leah instead of Rachel. ${ }^{50}$ Laban disguised Leah and made Jacob to have sex with her, thereby exploiting Jacob's love for Rachel in order to extend Jacob's stay with him and thus enjoying the labour and services of Jacob for another seven years. In defence of his scheme, Laban told Jacob, 'It is not our custom here to give the younger daughter in marriage before the older one' (29:26). The response is actually a rebuke to Jacob, the younger one who took the birth right and blessing of his older brother Esau. In this sense, Jacob is reminded of his past dubious dealings against his own brother. ${ }^{51}$

Similarly, Rachel also deceived Jacob and her father by stealing the idol of her father. While Jacob is represented as uttering a curse on anyone who took the said idol, the narrator, however, observed, '... Now Jacob did not know that Rachel had stolen the gods' (Genesis 31:31-32). Interestingly, like Jacob, Rachel here also stole the birth right because in ancient world the idols of the family are owned and possessed by the eldest son, but in this story, Rachel claimed this position by stealing the gods of her father. Consequently, she is indirectly claiming the right of primogeniture by stealing the idols in the same way Jacob stole the blessings of his father.

Climaxing this representation of nemesis is the deception of Jacob by his children in the selling of Joseph to Egypt. Like himself, they use the clothes of Joseph and poured the blood of a goat on it. This act also is reminiscent of Jacob's deception of his father in the earlier story. The scene bears similarity to that particular episode in several ways. For example, Esau's crying for the loss of his birth right is also seen in Jacob's crying for the loss of his beloved son. Like Esau, he himself is also here inconsolable. Apart of the crying

Frustration of Wisdom: Wisdom, Counsel and Divine Will in 2 Samuel 17:1-23,' JBL 128, no. 3 (2009), 464.

50 Describing the relationship of Jacob and Laban, Blenkinsopp observed, 'A great deal of Trickster activity characterizes the relations between uncle and nephew. Jacob the Trickster is out-tricked by Laban, in most spectacular fashion...' See Blenkinsopp, Treasures Old and New, 152.

51 See Blenkinsopp, Treasures Old and New, 152. 
scene in Genesis 33, here is the only scene describing the crying of Jacob. ${ }^{52}$ The crying itself converges and connects the earlier weeping of Esau and the one of Jacob here, thus forming a kind of inclusion. Considering these close connections, it appears that the narrator placed Jacob in three or four scenes of deception in order to reiterate the nemesis of a character who in earlier narrative was primarily a deceiver par excellence. By doing this, the narrator underscores his values and ethical stand that characters do not merely inhabit the worlds of his story without some moral moorings, but illustrate the importance of this view in the representation of the character Jacob. Within this lens, Jacob deceived his father, but he was also deceived in three places in almost the same way by the people he loved and trusted.

The same lesson possibly extended to the deception of Judah by Tamar. ${ }^{53}$ Judah played a formidable part in the selling of Joseph and the deception of his father. He is also subsequently hoodwinked by Tamar, thus suggesting that moral models in the patriarchal universe are not always crafted in moral ambiguity, but that the narrator provided the readers with clues to suggest that there is a moral template which guides the representations of characters and events in his stories. In this subtle way, there is a lofty ethical principle at work in Jacob's story that clearly underscores the place of divine retribution, and the recognition of Yahweh's justice to the characters within the patriarchal narratives. Describing the subtle punishment of Jacob in his representation in Genesis, Wenham said,

...after deceiving his father and cheating his brother, Jacob lives under a cloud of divine displeasure for most of the rest of his life. He is not simply forced to flee for his life and leave home, but in exile he suffers deception from his father-in-law by being forced to marry Leah...The unhappiness of his bigamous marriage to Leah and Rachel stalks Jacob for the rest of his life and spills over into the next generation as the sons of Leah gang up against the sons of Rachel, Joseph and Benjamin...To rub the point in that Jacob's sadness at the

52 See Mary Douglas, Jacob's Tears: The Priestly Work of Reconciliation (Oxford: Oxford University Press, 2004).

53 Judah also originally deceived Tamar by promising to give her Shelah his son, but he was unwilling to do so because he feared he will also die. This 'crooked' and 'deceptive intent' which resulted in Tamar's deceptive scheme as a payback. See Sharon, 'Some Results of a Structural Semiotic Analysis,'289-318, especially pages 301-306. 
apparent death of Joseph is in fact a consequence of his deception of his father...Thus if we read the story of Jacob's deception of his father within the context of the whole book of Genesis it becomes very difficult, if not impossible, to suppose the implied author is commending this action. It would be to read the story against the grain and impose on it a sense that is quite foreign to the writer's purpose. $^{54}$

Within this ethical template, the narrator of the Jacob's story avoided expressive moral comments to sanction the unethical behaviours of Jacob, but he nonetheless subtly presented his ethical viewpoint by the representations of Jacob in three important deception scenes. Through this connection, and the direct descriptions of his brokenness at the perceived death of Joseph, he points his reader to his displeasure at the dubious character of Jacob and his earlier duplicity against his father and brother. Considered in this way, the narrator imposes and shapes the overall direction and plots of his story by the use of hidden ethical system which indirectly seeks to retributively pay Jacob in the same coins of his earlier duplicity.

In its theological context, while at Bethel Yahweh appeared silent at the duplicity of Jacob against his father and brother (28: 9-22), but at Peniel he rose to confront Jacob in a fatal encounter (32: 22-32). In this midnight confrontation, Yahweh battled a dubious character Jacob till the point of dislocating the joint of his hip. It is important to note that the description of this encounter occurred in the middle of the tense story of his last meeting with his brother Esau (32:1-21; 33: 1-20). Through the placement of this encounter there, the narrator appears to underscore Yahweh's hostile confrontation against a crafty character who only now realized that he needs the blessing of the divine emissary. With limping feet, he now approached his brother Esau, and it seems this encounter has radical transformative effects on his subsequent conversation with his brother. Like the wrestle with his brother at birth, he now wrestles with the divine being (25: 24-34). Even though there is no element of rebuke in the Peniel story against Jacob's duplicity, the strategic placement of this story at the moment when he is

54 Wenham, Story as Torah, 76. 
about to meet his brother indicates the narrator's overall quest to connect this story to the earlier dubious wrestling of Jacob with his brother. By the dislocation and limping of Jacob, Yahweh clearly undertakes to confront and even broke the bones of a dubious character in his quest to redirect and fulfil his covenantal plans for him and his descendants after him.

\section{The characterization of Jacob and its significance}

Having presented the patriarchal narratives from the preceding ethical angle, it is important to underscore the general significance of this representation of Jacob in particular especially its importance to the literary representations in the patriarchal narratives. There are at least five important significance of the preceding characterization of Jacob in Genesis. First, the narrator subtly presented the character of Jacob, and closely connected this character to scenes which called to mind his initial duplicity, thus suggesting that the narrative world has underlying moral mooring. The narrator's ethical commitment clearly surfaces in the intriguing ways he connects the different scenes of deceptions around Jacob, and places him as the object of deception rather than its subject. In doing this, the narrator points to his ethical commitment and values, thereby underscoring his moral sensitivity. Second, the narrator appears to distance himself from making explicit moralizing comments. ${ }^{55}$ In this way, the narrator adds complexity and depth to the ethical representation of his characters. Third, in distancing himself from his characters the narrator introduces a nearly objective description of the events and characters within the stories, thereby helping the readers to take sides and judge things themselves, rather than imposing his ethical views on the readers. On this level, he refuses to whitewash his heroes or to totally demonize his villains. Fourth, by presenting a moral universe filled with complexities, he mimetically seeks to capture morality in real life and to show how heroes in real life also suffer from moral flaws. In fact, the narrator presents his characters with the imperfection of their personalities and thus seeks to

55 Concerning this reticence in the narrator voicing his moral judgment, Wenham observed, the biblical narratives 'seldom contain explicit moral judgments, but much more often leave the events to speak for themselves, thereby encouraging the reader to reflect on and relate past events to him-or herself in the present. Where however there is a danger that the reader might misjudge the situation, an authoritative comment may be heard.' See Wenham, Story as Torah, 14. 
mirror reality in this moral sense. Lastly, from the prism of biblical theology, this representation of Jacob gives justification to the salvific message of the gospel and reiterate the necessity of the incarnation, since the heroes of our stories, whether in reality or biblical stories, have imperfections that need saving. Consequently, the moral flaws of patriarchs in general and Jacob in particular provided theological basis for salvation since it makes clear our fallenness as human beings. In its biblical framework, God maintains his covenant with Jacob, despite Jacob's failings, and the gracious dealing of God towards the patriarchs generally points forward to God's salvific plan, which finds its realization in the incarnation.

\section{Conclusion}

The ethical imagination of the patriarchal narratives appeared on a surface reading to be grossly primitive and viciously inadequate as a moral guide. The patriarchal ethics in this sense seems formidably troubling to the modern reader particularly when compared to the Mosaic legislation or the high morality of the New Testament revelation. Yet, in spite of the disturbing ethical mapping of the patriarchal stories, there are indications which point to the subtle quest by the narrator to ground his stories in strong moral moorings. This ethical stance is conveyed without the intruding and distracting comments of the narrator rather it is conveyed by means of representation of the events and characters of his stories. In the characterization of Jacob in particular, the narrator conveyed his ethical viewpoints and values by the connection of Jacob with three scenes of deception where Jacob himself becomes the object and victim of deception. On the long run, Jacob becomes an important starting point in negating the contemporary assumptions that patriarchal stories lacked any define moral mooring. Against this position, Jacob's duplicity is not only punished and rejected but the characterization of Jacob and God in the patriarchal narratives provided the appropriate background for the thriving of a New Testament theology which aptly celebrates the love and compassionate of God to stubborn and Jacob-like sinners in the contemporary world. Placed on these different horizons, the characterization of Jacob throws light to the ethical mapping of the patriarchal narratives, but it also significantly opens a defining chapter in the divine/human relationships within biblical theology. 


\section{Bibliography}

Anderson, John E 2011. Jacob and the Divine Trickster: A Theology of Deception and Yhwh's Fidelity to the Ancestral Promise in the Jacob Cycle. Winona Lake: Eisenbrauns.

Bar-Efrat, Shimon 2008. Narrative Art in the Bible. New York: T\&T Clark, 2004, reprint 2008.

Barton, John 2003. Understanding Old Testament Ethics: Approaches and Explorations. Louisville, KY: Westminster John Knox Press.

Bird, Michael F 2013. 'Patriarchs and Israel,' in Evangelical Theology: A Biblical and Systematic Introduction, 500-506. Grand Rapids, Michigan: Zondervan.

Blenkinsopp, Joseph. 'Abraham as Paradigm in Priestly History of Genesis.' JBL 128, no. 2 (2009): 225-241.

Blenkinsopp, Joseph 2004. Treasures Old and New: Essays in the Theology of the Pentateuch. Grand Rapids, Michigan: Eerdmans.

Booth, Wayne 1961. Rhetoric of Fiction. Chicago: University of Chicago.

Carroll, M Daniel, et al, eds 2007. Character Ethics and the Old Testament: Moral Dimensions of Scripture. Louisville, KY: Westminster.

Douglas, Mary 2004. Jacob's Tears: The Priestly Work of Reconciliation. Oxford: Oxford University Press.

Driver, S R 1904. The Book of Genesis. London: Methuen.

Figlerowicz, Marta. 'Bounding the Self: Ethics, Anxiety, and Territories of Personhood in Samuel Beckett's Fiction.' Journal of Modern Literature 34, no. 2 (2011): 76-96.

Green, Ronald M. 'Abraham, Isaac, and the Jewish Traditions: An Ethical Reappraisal.' The Journal of Religious Ethics 10, no. 1 (1982), 1-21.

Gunkel, Herman 1977. Genesis (Göttingen: Vandenhoeck \& Ruprecht. Hester, Joseph 2003. The Ten Commandments: A Handbook of Religious, Legal and Social Issues. Jefferson, NC: McFarland. 
Jackson, Melissa. 'Lot's Daughters and Tamar as Tricksters and the Patriarchal Narratives as Feminist Theology.' JSOT 98 (2002): 29-46.

Kierkegaard, Søren 2008. Fear and Trembling. Radford, VA: Wilder Publication.

Lasine, Stuart. 'Everything Belong to Me: Holiness, Danger, and Divine Kingship in the Post-Genesis World.' JSOT 35, no. 1 (2010): 31-62.

Leveen, Adriane. 'Reading the Seams,' JSOT 29, no. 3 (2005): 259-287.

Levin, Christoph. 'The Yahwist: The Early Editor in the Pentateuch.' JBL 125, no. 2 (2007):209-230.

Mills, Margaret A. 'The Gender of the Trick: Female Tricksters and the Male Narrators.' Asian Folklore Studies 60, no. 2 (2001): 237-258.

Moltz, Howard. 'God and Abraham in the Binding of Isaac.' JSOT 96 (2001): 59-69.

Mooney, Edward F. 'Abraham and Dilemma: Kierkegaard's Teleological Suspension Revisited.' International Journal for Philosophy of Religion 19 (1986): 23-41.

Newton, Adam Z 1995. Narrative Ethics. Cambridge, MA: Harvard University Press.

Nicholas, Dean A 2009. The Trickster Revisited: Deception as a Motif in the Pentateuch. Oxford: Peter Lang, 2009.

Park, Song-mi S. 'The Frustration of Wisdom: Wisdom, Counsel and Divine Will in 2 Samuel 17:1-23.' JBL 128, no. 3 (2009): 453-467.

Parry, Robin 2004. Old Testament Story and Christian Ethics: The Rape of Dinah as a Case Study. Milton Keynes: Paternoster Press.

Petersen, David L. 'Genesis and Family Values,' JBL 124, no. 1 (2005): 5-23.

Prouser, O H. 'The Truth about Women and Lying,' JSOT 61 (1994): 15-28.

Reiss, Moshe. 'The God of Abraham, Rebekah, and Jacob.' Jewish Bible Quarterly32, no. 2(2004): 1-7. 
Schindler, Pesach. 'Jacob and Esau Revisited: Demon versus Tzadik.' Jewish Bible Quarterly 35, no. 3 (2007): 153-160.

Sharon, Diane M. 'Some Results of a Structural Semiotic Analysis of the Story of Judah and Tamar,' JSOT 29, no. 3 (2005): 289-318.

Skinner, John 1930. A Critical and Exegetical Commentary on Genesis.

ICC. Edinburgh: T\&T Clark, 1930.

Sternberg, Meir 1987. The Poetics of Biblical Narrative: Ideological

Literature and the Drama of Reading. Bloomington: Indiana

University Press.

Von Rad, Gerhard 1959. Genesis: A Commentary, trans. John H Marks. Philadelphia: The Westminster Press.

Walsh, Richard. 'Fictionality and Mimesis: Between Narrativity and Fictional Worlds.' Narrative 11, no. 1 (2003): 110-121.

Watke, Bruce and Cathi J Fredericks 2001. Genesis. Grand Rapids, Michigan: Zondervan, 2001.

Wenham, Gordon J 2000. Story as Torah: Reading the Old Testament Ethically. Edinburgh: T. \& T. Clark, 2000.

Williams, Michael J 2001. Deception in Genesis: An Investigation into the Morality of a Unique Biblical Phenomenon. Studies in Biblical Literature, vol. 32. New York: Peter Lang.

Wright, Christopher J H 2004. Old Testament Ethics for the People of God. Leicester, England: Inter-Varsity. 